\title{
Evaluasi penyelenggaraan program keahlian keperawatan di Sekolah Menengah Kejuruan (SMK)
}

\author{
Sima Fatmawati *, Bambang Suteng Sulasmono \\ Fakultas Keguruan dan Ilmu Pendidikan, Universitas Satya Wacana. \\ Jl. Diponegoro No.52-60, Salatiga, Sidorejo, Jawa Tengah 50711, Indonesia. \\ simafatma24@gmail.com \\ * Corresponding Author
}

\section{ARTICLE INFO}

\section{Article History}

Received:

12 April 2020;

Revised:

25 May 2020;

Accepted:

29 May 2020

\section{Keywords}

CIPP;

Evaluasi program;

Keperawatan;

Nursing;

Program evaluation

\begin{abstract}
Penelitian ini bertujuan untuk melakukan analisis terhadap jalannya penyelenggaraan program keahlian keperawatan di tingkat sekolah menengah kejuruan. Jenis penelitian ini adalah penelitian evaluasi mengguna-kan pendekatan dekriptif kualitatif dengan model evaluasi CIPP. Subyek pada penelitian ini adalah kepala sekolah, wakil kepala kurikulum, wakil kepala sarana dan prasarana, ketua program keahlian keperawatan, bursa kerja khusus, guru keperawatan, dan pegawai tata usaha. Teknik pengumpulan data penelitianini menggunakan observasi, wawancara, dan studi dokumentasi. Pada penelitian ini mengunakan teknik analisis data Miles dan Huberman. Validasi data dilakukan dengan triangulasi teknik dan triangulasi sumber. Hasil penelitian menunjukkan komponen context dalam kategori baik, komponen input dalam kategori baik, komponen process dalam kategori baik tetapi terdapat beberapa kendala, komponen product dalam kategori cukup karena tidak memenuhi kriteria yang ditentukan yaitu jumlah kesesuaian kerja lulusan kurang dari 50\%.
\end{abstract}

This research aims to analyze the implementation of the nursing skills program at the vocational high school level. The type of research is evaluation research using a qualitative descriptive approach with the CIPP evaluation model. The subjects in this research were the headmaster, deputy head of curriculum, deputy head of facilities and infrastructure, head of nursing expertise program, special job fair, nursing teachers, and administrative staff. The research data collection technique uses observation, interviews, and documentation studies. Data validation uses technical triangulation and source triangulation. The results showed the context component was in the good category, the input component was in a good category, Process components are in good category but there are some constraints, while the product component in the sufficient category because it does noit meet the specified criteria, the amount of work suitability of graduates is less $50 \%$.

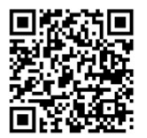

This is an open access article under the $\underline{\mathrm{CC}-\mathrm{BY}-\mathrm{SA}}$ license.

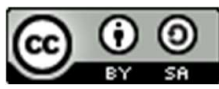

How to cite:

Fatmawati, S., \& Sulasmono, B. S. (2020). Evaluasi penyelenggaraan program keahlian keperawatan di Sekolah Menengah Kejuruan (SMK). Jurnal Akuntabilitas Manajemen Pendidikan, 8(1), 1-9.

doi:https://doi.org/10.21831/jamp.v8i1.31163 


\section{PENDAHULUAN}

Pendidikan vokasi merupakan jalur pendidikan penting yang dapat digunakan untuk membangun SDM Indonesia yang memiliki daya saing global, karena untuk menjadi negara maju tidak hanya ilmuwan dan tenaga ahli saja yang diperlukan, tetapi juga memerlukan tenaga kerja yang memiliki keterampilan sesuai dengan bidangnya (Hermawan \& Fatimah, 2017; Soesatyo \& Ilyasa, 2018; Hikam \& Sari, 2017). Salah satu pendidikan vokasi dari uraian tersebut adalah di tingkat pendidikan menengah atau yang sering disebut SMK. Pendidikan vokasi memiliki peran yang cukup penting dalam membangun daya saing global khususnya SMK dalam pendidikan nasional merupakan bentuk dari satuan pendidikam yang berorientasi untuk membekali siswa dalam memasuki dunia kerja ditingkat menengah, dan melanjutkan lagi pendidikan ke jenjang yang lebih tinggi sesuai dengan kekhususannya (Hamalik, 2001; Evans dalam Muliati, 2007; Djohar, 2007). Pendidikan dasar dalam keterampilan, pengembangan bakat, maupun kebiasaan yang mengarahkan pada dunia kerja merupakan bekal yang siswa dapatkan di SMK. Pembelajaran pun tidak hanya dilakukan di sekolah, namun diikuti dengan kegiatan praktik kerja lapangan di dunia kerja nyata yang bertujuan untuk meningkatkan pengalaman belajar dan ketrampilan bekerja siswa.

Tetapi disisi lain hasil penelitian Ixtiarto dan Sutrisno (2016) menyatakan kemitraan yang dilakukan dengan Du/Di kurang optimal, sehingga kompetensi peserta didik terhadap tempat kerja yang ditempati setelah lulus belum menunjukan kesesuaian. Sejalan dengan itu penelitian Mutaqin, Kusnawa, dan Sriyono (2015) tentang studi eksplorasi keterserapan lulusan SMK Negeri di kota Bandung menyatakan bahwa keterserapan lulusan SMK masih kurang dari setengah. Hasil penelitian Ngadi (2014) tentang relevansi atau kesesuaian antar pendidikan kejuruan dengan pasar kerja yang ada di kota Salatiga menyatakan bahwa masih terdapat $12 \%$ lulusan dari SMK tidak terserap pada dunia kerja. Lulusan SMK yang dipersiapkan untuk memasuki dunia kerja, ternyata juga rendah kesesuaian kerjanya di dunia kerja. Kondisi serupa juga terjadi pada SMK PGRI 1 Salatiga, dimana keterserapan lulusan program keahlian keperawatan SMK PGRI 1 Salatiga untuk pekerjaan linier selalu mendapatkan prosentase terkecil dibanding pekerjaan tidak linier dan studi ke Perguruan Tinggi, yaitu: 6,25\% di tahun 2017, 20\% di tahun 2018 dan 75\% di tahun 2019. Selain masalah tersebut juga terjadi ketidakstabilan dalam penerimaan peserta didik baru tiap tahunnya, dimana terjadi penurunan jumlah peserta didik baru pada tahun ajaran 2017-2018 hingga 2019-2020.

Dengan demikian dalam rangka meningkatkan kualitas pendidikan pada program keahlian keperawatan yang masih terus berjalan, kedua hal tersebut menjadi latar belakang kajian dilakukannya evaluasi penyelenggaraan program keahlian keperawatan di SMK PGRI 1 Salatiga. Kegiatan evaluasi tersebut bertujuan untuk mengidentifikasi dan mengetahui sejauh mana ketercapaian, kekurangan dan kebijakan tindak lanjut yang perlu dilakukan oleh sekolah guna meningkatkan kemajuan penyelenggaraan program keahlian keperawatan di SMK PGRI 1 Salatiga.

\section{METODE}

Deskriptif kualitatif merupakan pendekatan yang digunakan dalam penelitian evauasi ini. Penelitian ini akan menggunakan model evaluasi CIPP (Context, Input, Process, Product) oleh Stufflebeam. Adapun subyek pada penelitian ini adalah kepala sekolah, waka kurikulum, waka sarpras, ketua program keahlian keperawatan, BKK (Bursa Kerja Khusus), guru keperawatan, dan pegawai tata usaha. Teknik pengumpulan informasi data penelitian yang digunakan meliputi: kegiatan observasi, wawancara, dan studi dokumentasi. Uji validasi pada penelitian ini dengan triangulasi teknik dan triangulasi sumber. Kegiatan analisis data penelitian ini, yaitu: 1.) Mengkoleksi data; 2.) Mereduksi data; 3.) Mendisplay data; dan 4.) Memverifikasi atau menarik kesimpulan data (Sugiyono, 2013, p. 335). Kriteria evaluasi pada penelitian ini menggunakan kriteria kualitatif tanpa pertimbangan oleh Arikunto dan Jabar (2014, p. 36), dimana kriteria evaluasi yang disusun berdasarkan dengan menghitung jumlah indikator dalam komponen yang telah memenuhi persyaratan. 


\section{HASIL DAN PEMBAHASAN}

Hasil

Tahap evaluasi context dalam penelitian ini akan dibahas mengenai latar belakang, tujuan, kebutuhan, asset, peluang dan manfaat dari diselenggarakannya program keahlian keperawatan di tahun ajaran 2018/2019. Latar belakang masih diselenggarakannya program keahlian keperawatan di SMK PGRI 1 Salatiga adalah karena program keahlian tersebut masih memiliki banyak peminat dibanding dua program keahlian lain yaitu tata busana dan analis kesehatan, sehingga sekolah memiliki kebutuhan untuk memfasilitasi peminat program keahlian keperawatan yang masih ada.

Selain itu di tengah berkembangnya era revolusi industri 4.0 membuat semakin ketatnya kompetisi di bidang pendidikan menengah kejuruan atau vokasi, sehingga menjadi kebutuhan sekolah untuk menjawab tantangan tersebut dengan tetap menyelenggarakan program keahlian keperawatan. Program keahlian keperawatan dipilih karena pekerjaan yang dilakukan seorang perawat kecil kemungkinan untuk digantikan dengan mesin apapun, karena seorang perawat harus bersentuhan langsung dengan pasien dalam memberikan asuhan atau pelayanan yang berhubungan dengan nyawa seseorang.

Selain melihat kebutuhan yang hendak dipenuhi dalam menyelenggarakan program keahlian keperawatan tahun ajaran. 2018/2019, sekolah juga mempertimbangkan aspek aset yang dimiliki untuk mendukung penyelenggaraan program tersebut. Aset pendukung yang dimiliki meliputi ruang kelas, $L C D$, proyektor, lab keperawatan, laboratorium IPA, alat-alat kesehatan, laboratorium komputer, perpustakaan, dan toilet. Peluang sekolah untuk menyelenggarakan program keahlian keperawatan di tahun ajaran 2018/2019 sangat besar mengingat program keahlian tersebut belum berembang dan belum banyak dimiliki oleh sekolah lain yang ada di Salatiga. Dengan adanya kebutuhan dan peluang diatas maka manfaat yang diperoleh dengan menyelenggarakan program keahlian keperawatan yaitu dapat mencetak lulusan yang mampu bersaing ditengah perkembangan era revolusi industri yang semakin meningkat, dan juga dapat menyeimbangkan finansial sekolah dengan adanya peminat yang memlilih program keahlian keperawatan.

Evaluasi pada komponen Input dalam program keahlian keperawatan meliputi program, perencanaan kegiatan pada program, ketersediaan SDM, ketersediaan sarana prasarana, alokasi angggaran atau pendanaan, serta mekanisme pelaksanaan kegiatan pada program. Terkait dengan perencanaan untuk penyelenggaraan program keahlian keperawatan tahun ajaran 2018/2019, sekolah memiliki beberapa agenda yaitu PPDB tahun ajaran 2018/2019, pengembangan kurikulum, rapat kerja, kegiatan belajar mengajar yang memiliki beberapa bagian, dan caping day ceremony. Sumber daya manusia di SMK PGRI 1 Salatiga program keahlian keperawatan terdiri dari 17 tenaga pendidik. Tenaga pendidik tersebut terdiri dari 6 guru laki-laki dan 11 guru perempuan, dimana diantaranya memiliki kualifikasi pendidikan S2 sebanyak 4 guru, S1 sebanyak 10 guru dan D3 sebanyak 3 Guru. Sarana dan prasarana yang dibutuhkan program keahlian keperawatan adalah dengan dokumen sekolah sebagai berikut: lahan kosong seluas $2525 \mathrm{~m}^{2}$, gedung sekolah seluas 2870 $\mathrm{m}^{2}$, ruang kelas sebanyak 15 kelas, halaman dan lahan parkir, 1 ruang praktik, 6 toilet, alat-alat praktikum ( 6 bed pasien, 1 meja receptionis, 12 troli, 6 washtafel, 4 etalase penyimpan alat, 1 sterilisator, 6 set alat medis, phantom, 3 set tabung oksigen, 10 tensi meter, 20 stetoskop, 20 termometer). Sumber dana dalam menyelenggaraan program keahlian keperawatan SMK PGRI 1 Salatiga berasal dari dana pribadi sekolah dan juga dana dari pemerintah/ dana BOS. Mekanisme dari pelaksanaan kegiatan yang telah direcanakan memiliki waktu pelaksanaan dan capaian taget pada masing-masing kegiatan.

Evaluasi pada komponen process dalam penyelenggaraan program keahlian keperawatan meliputi bagaimana implementasi dari perencanaan yang telah dibuat, efektivitas sarpras dari tiaptiap perencanaan, eifisiensi dana, kinerja SDM yang terlibat, serta kendala dan permasalahan yang mungkin dihadapi saat mengimplementasikan perencanaan yang telah disusun. Implementasi perencanaan PPDB pada program keahlian keperawatan di SMK PGRI 1 Salatiga TA.2018/2019 berjalan sesuai rencana yang telah disusun, dengan mekanisme pelaksanaan pada kurun waktu tujuh bulan yaitu Januari 2018 sampai dengan Juli 2018 dengan perolehan siswa sebanyak 117. 
Sumber daya manusia yang terlibat adalah guru dan karyawan yang sudah terbiasa menagani pendaftaran peserta didik baru, selain itu khususnya untuk cek kesehatan ditangani oleh guru dari program keahlian keperawatan dibantu dengan beberapa siswa. Sedangkan sarana dan prasarana yang digunakan meliputi: ruang kelas beserta meja kursi untuk calon pendaftar, toilet untuk cek urine, alat kesehatan seperti tensi, thermometer, strip cek urine, stetoskop, timbangan, alat pengukur tinggi badan, handsoon dan masker. Untuk biaya yang digunakan sesuai dengan rencana anggaran yang telah dibuat, biaya tersebut digunakan untuk pemasangan spanduk promosi sekolah, penyebar luasan brosur promosi sekolah, dan pembelian alat kesehatan yang masuk kategori barang habis pakai.

Kendala yang sekolah hadapi saat PPDB adalah kekurangan personil dan sarana penunjang seperti LCD, proyektor dan laptop apabila ada jadwal presentasi yang bersamaan. Implementasi pengembangan kurikulum program keahlian keperawatan di SMK PGRI 1 Salatiga berlangsung pada tanggal 2 Juli 2018, sumber daya manusia yang terlibat yaitu sebagai pihak dalam Kepala Sekolah, kurikulum dan kaproli keperawatan, dan pihak luar sekolah yaitu Du/Di (Rumah Sakit dan Klinik). Hal tersebut bertujuan supaya mendapatkan kesesuaian antara pengajaran disekolah dengan tuntutan $\mathrm{Du} / \mathrm{Di}$, serta penandatanganan MoU kerjasama untuk pembelajaran siswa diluar kelas atau PKL. Dalam implementasi pengembangan kurikulum juga memanfaatkan sarana dan prasarana yang ada di sekolah seperti: meja, kursi, ruang kelas, LCD, proyektor. Sedangkan dana yang digunakan untuk mengundang dan menjamu tamu atau $\mathrm{Du} / \mathrm{Di}$.

Implementasi dari perencanaan IHT berjalan sesuai mekanisme yang telah disusun. SDM yang terlibat dalam IHT adalah guru dan karyawan SMK PGRI 1 Salatiga, dimana mereka diwajibkan untuk membuat perangkat pembelajaran sesuai dengan mata pelajaran yang diampu, dan karyawan membuat program kerja sesuai dengan bagiannya. Sarana dan prasarana yang digunakan yaitu dengan memanfaatkan ruang kelas beserta isinya ditambah dengan LCD dan proyektor. Sedangkan dana yang digunakan sesuai dengan perencanaan. Kendala yang dihadapi saat melaksanakan kegiatan IHT adalah keterlambatan beberapa guru yang tidak tepat waktu dalam mengumpulkan perangkat pembelajara hasil IHT tersebut. Implementasi KBM dalam program keahlian keperawatan terlaksana sejak bulan Juli 2018 sampai dengan bulan Juni 2019 terdiri dari dua bagian yaitu pembelajaran di dalam kelas dan pembelajaran di luar kelas. Pembelajaran di dalam kelas menunjukkan guru telah memanfaatkan sarana dan prasarana yang tersedia, selain itu guru juga memanfaatkan laboratorium keperawatan untuk mendemostrasikan asuhan apa yang diberikan kepada pasien. Untuk pembelajaran di dalam kelas, di kelas X dan XI pada setiap tengah semester diadakan (PTS), pada akhir semester satu diadakan penilaian akhir semester (PAS), dan pada akhir semester dua diadakan penilaian akhir tahun (PAT).

Khusus kelas XII teknisnya sama hanya saja pada pelaksanaan PAT diganti dengan USBN, UNBK dan UKOM. Dimana UKOM dilakasanakan dengan melibatkan pihak luar yaitu Lembaga Sertifikasi Profesi (LSP) yang didatangkan untuk menguji kompetensi siswa kelas XII. Sedangkan pembelajaran di luar kelas berupa kegiatan Kunjungan Industri (KI) yang dilakukan kelas XI dengan mengunjungi Rumah Sakit Ortopedi Solo dan Balai Besar Pengendalian Penyakit dan Lingkungan yang ada di Jogjakarta. Pembelajaran di luar kelas yang lain adalah Praktik Kerja Lapangan (PKL) yang dilakukan siswa kelas XII pada awal semester satu selama tiga bulan di Rumah Sakit dan Klinik yang telah memiliki MoU dengan sekolah. Dan untuk biaya yang digunakan dalam satu tahun ajaran 2018/2019 termasuk untuk membayar pihak LSP. Adapun kendala yang dihadapi saat pembelajaran yaitu pengaturan jadwal penggunaan laboratorium keperawatan yang terkadang bersamaan antara kelas satu dan yang lain. Implementasi kegiatan caping day berjalan sesuai dengan apa yang telah direncanakan yaitu berlangsung pada tanggal 22 Desember 2018 dan bersamaan dengan pembagian raport hasil belajar pada siswa kelas X. Kegiatan caping day memiliki tujuan untuk mengenalkan bagaimana sejarah perawat dunia sekaligus penyematan topi perawat dan mengucapkan sumpah janji asiten keperawatan sebelum pada siswa dapat terjun langsung untuk menangani pasien ketika PKL dilakukan. SDM yang terlibat merupakan guru dan karyawan SMK PGRI 1 Salatiga.

Besar dana yang digunakan untuk seluruh kebutuhan dalam kegiatan caping day, nominalnya bisa berbeda setiap tahunnya, karena tergantung banyaknya jumlah peserta pada tiap angkatan. Akan tetapi terdapat kendala terkait tempat acara, dimana pada acara itu mendatangkan selurus siswa kelas $\mathrm{X}$ beserta orang tuanya dan sekolah belum memiliki aula sesuai kapasitas tamu 
undangan sehingga yang harus menyewa di luar. Pada tahap evaluasi product dalam penelitian ini akan dibahas tentang jumlah lulusan, kualitas lulusan, dan juga keterserapan lulusan khususnya pada tahun ajaran 2018/2019 program keahlian keperawatan di SMK PGRI 1 Salatiga. Jumlah lulusan program keahlian keperawatan SMK PGRI 1 Salatiga yang mengalami penurunan peserta didik yang masuk pada tahun ajaran 2016-2017 dengan jumlah 77 peserta didik tetapi pada saat kelulusan tahun 2019 hanya 75 peserta didik atau sama dengan 97\% peserta didik yang lulus. Hal tersebut dikarenakan beberapa siswa melakukan pencabutan berkas dari sekolah dengan berbagai alasan, seperti masalah keluarga, biaya, maupun minat belajar yang menurun.

Kualitas lulusan program keahlian keperawatan di SMK PGRI 1 Salatiga adalah semua siswa dinyatakan lulus uji kompetensi dan mendapatkan predikat kompeten oleh LSP. Pernyataan tersebut didukung dengan dokumen berupa hasil UKOM peserta didik dalam bentuk sertifikat UKOM tahun ajaran 2018/2019. Dari 75 lulusan terdapat 30 lulusan bekerja tidak linier dengan program keahlian keperawatan, 25 memilih untuk melanjutkan ke perguruan tinggi, dan 20 lulusan telah bekerja sesuai dengan program keahlian keperawatan. Terlihat bahwa jumlah lulusan yang bekerja tidak linier dengan program keahlian keperawatan adalah paling banyak. Hal tersebut karena lowongan pekerjaan untuk lulusan program keahlian keperawatan sebagian besar berada di luar kota Salatiga, dan sebagian besar lulusan enggan untuk mengambilnya dengan alasan bahwa masih tidak bisa hidup terpisah dari orang tuanya. Sehingga mereka lebih memilih menetap di Salatiga dan bekerja tidak sesuai dengan bidang kehaliannya.

Pembahasan

Berdasarkan hasil penelitian tentang evaluasi context pada program keahlian keperawatan SMK PGRI 1 Salatiga ditemukan bahwa sekolah memiliki latar belakang mengapa program keahlian keperawatan masih diselenggarakan, yaitu karena program keahlian keperawatan masih memiliki peminat paling banyak diantara program keahlian lain yang ada di sekolah (tata busana dan analis kesehatan) dan persaingan yang ketat dengan sekolah lainnya dalam memperoleh peseta didik baru, Sehingga dari latar belakang tersebut sekolah memiliki beberapa kebutuhan yang belum terpenuhi, diantaranya adalah memfasilitasi para peminat program keahlian keperawatan yang masih ada serta kebutuhan untuk menjawab tantangan di era revolusi industri 4.0 yang menunjukkan persaingan yang semakin ketat melalui pendidikan. Era revolusi industri semakin berkembang pesat, dimana nantinya hampir semua jenis pekerjaan bisa digantikan dengan teknologi mesin.

Untuk itu pihak sekolah harus mampu menjawab tantangan era revolusi tersebut supaya tetap bisa memberdayakan manusia, caranya adalah dengan tetap menyelenggarakan program keahlian keperawatan. Hal tersebut didasari oleh asumsi karena pekerjaan seorang perawat kecil kemungkinan untuk digantikan dengan mesin apapun, karena seorang perawat harus bersentuhan langsung dengan pasien dalam memberikan asuhan atau pelayanan yang berhubungan dengan nyawa seseorang. Hal tersebut sesuai dengan Undang Undang Nomor 38 Tahun 2014 yang menyatakan bahwa keperawatan merupakan kegiatan-kegiatan dimana memberikan asuhan pada keluarga, individu, maupun kelompok masyarakat yang berada dalam kondisi sehat maupun sakit.

Secara umum sekolah memiliki potensi atau aset dalam sarana dan prasarana yang semakin lengkap dari tahun ke tahun, sehingga memungkinkan untuk tetap menyelenggarakan program kehalian keperawatan di tahun ajaran 2018/2019. Hal lain yang juga menjadi pertimbangan yaitu sekolah memiliki peluang yang sangat besar apabila program keahlian keperawatan itu tetap berjalan, peluang tersebut yaitu masih minimnya sekolah menengah kesehatan di Salatiga khususnya program keahlian keperawatan. Dari uraian tentang peluang tersebut maka selain untuk menjaga keberlangsungan sekolah di era revolusi industri 4.0, sekolah juga memiliki tujuan untuk mengembangkan program keahlian keperawatan di Salatiga dengan memfasilitasi pendidikan bagi calon perawat dan memberikan sumbangan ilmu bagi profesi perawat ataupun masyarakat. Hal tersebut senada dengan pendapat yang dikemukakan oleh Husin (dalam Lestari, 2018, p. 77) bahwa pendidikan keperawatan diharapkan mampu memfasilitasi pembentukan komunitas perawat dalam hal memberikan sumbangan ilmu bagi profesinya maupun bagi masyarakat.

Dengan demikian komponen context pada Penyelenggaraan Program Keahlian Keperawatan di SMK PGRI 1 Salatiga TA. 2018/2019 didasarkan pada kebutuhan stakeholder dan masyarakat 
dengan memperhatikan aspek lain seperti: asset, peluang yang dimiliki, dan tujuan program tersebut. Hal tersebut senada dengan Stufflebeam (dalam Wirawan, 2012, p. 92) bahwa evaluasi context berupaya untuk melakukan identifikasi terhadap kebutuhan lingkungan yang belum terpenuhi, aset, peluang, dan juga tujuan dari program. Dapat disimpulkan bahwa penyelenggaraan program keahlian keperawatan di SMK PGRI 1 Salatiga tahun ajaran 2018/2019 termasuk dalam kategori baik. Hal tersebut senada dengan penelitian oleh Novi Hendri Adi (2018) yang menyatakan bahwa komponen context pada evaluasi program di SMK Negeri 2 Lubuk Basung masuk dalam kategori baik, meskipun memiliki kriteria evaluasi berbeda.

Komponen input pada evaluasi penyelenggaraan program keahlian keperawatan SMK PGRI 1 Salatiga yaitu perencanaan yang dilakukan sekolah dalam menyelenggarakan program keahlian keperawatan diawali dengan menyusun rencana kegiatan apa saja yang akan dilakukan selama satu tahun ajaran. Kegitan tersebut adalah Penerimaan Peserta Didik Baru (PPDB), Pengembangan Kurikulum, In House Training (IHT), Kegiatan Belajar Mengajar (KBM), dan Caping Day Ceremony. PPDB dilaksanakan untuk memperoleh peserta didik baru sebanyak-banyaknya melalui media online maupun offline, cara tersebut cukup efektif menarik minat peserta didik baru untuk masuk program keahlian keperawatan. Kemudian pengembangan kurikulum dilaksanakan dengan melibatkan Du/Di (rumah sakit atau klinik) dengan tujuan supaya kurikulum yang disusun bisa menjadi acuan sekolah menyusun bahan ajar yang sesuai dengan kebutuhan di dunia kerja maupun pendidikan nasional, senada dengan Suparlan (2011, p. 79 ) yang menyatakan bahwa pengembangan kurikulum merupakan proses dalam merencanakan dan menyusun sebuah kurikulum supaya menghasilkan kurikulum yang bisa menjadi acuan dalam membuat bahan ajar yang sesuai dengan pendidikan nasional.

Sedangkan untuk struktur kepengurusan program keahlian keperawatan telah disampaikan dalam kegiatan In House Training (IHT) melalui SK Kepala Sekolah Nomor 423.5.200/2018 yang didalamnya memuat tentang pembagian tugas setiap anggota. Dengan disampaikannya struktur kepengurusan tersebut menunjukkan bahwa program keahlian keperawatan telah memiliki tim yang bertanggungjawab terhadap terlaksananya program. Hal tersebut senada dengan Prihantono (2012: 43) yang menyatakan bahwa dalam organisasi memiliki pengaturan pekerjaan maupun pembagian tugas setiap angota untuk mencapai tujuan bersama. Selanjutnya Kegiatan Belajar Mengajar (KBM) pada program keahlian keperawatan, telah direncanakan pada setiap semesternya akan diadakan dua kali penilaian yaitu penilaian tengah semester dan penilaian akhiir semester. Pada semester kedua untuk siswa kelas XII diadakan ujian yang meliputi USBN, UNBK, dan UKOM. Selain itu, juga direncanakan kegiatan caping day, kunjungan industri dan praktik kerja lapangan sebagai pembelajaran diluar kelas untuk meningkatkan pengetahuan dan kualitas siswa dari pengalaman yang didapatkannya. Hal tersebut senada dengan pendapat Yuliarto $(2012$, p. 2) bahwa pembelajaran diluar kelas merupakan alterntive untuk meningkatkan pengetahuan dan kualitas seseorang dari segala pengalaman yang dia dapatkan. Seluruh perencanaan tersebut telah memiliki mekanisme pelaksanaan yang juga sudah ditentukan kapan kegiatan itu akan dilaksanakan.

Sedangkan sumber daya manusia yang terlibat didalamnya merupakan SDM yang memiliki kualifikasi dibidangnya. Hal itu didukung dengan dokumen mengenai ijazah para pendidik, sehingga dalam menyelenggarakan program keahlian keperawatan di tahun ajaran 2018/2019 sekolah tidak terlalu kesulitan dalam pemenuhan SDM. Terkait sumber dana yang digunakan untuk menyelengrakan program keahlian keperawatan bersumber dari dana Bantuan Operasional Sekilah (BOS) dan dana komite atau subsidi dari masing-masing orang tua siswa yang sudah melalui kesepakatan dan rapat dengan pihak sekolah. Berdasarkan hasil temuan dilapangan, fasilitas yang dimiliki sekolah untuk menunjang terselenggaranya program kehalian keperawatan sudah cukup memadahi dan dapat memenuhi kebutuhan siswa, baik dari segi ruang kelas, laboratorium, maupun alat kesehatan yang perlu digunakan, sehingga dalam segi sarana dan prasarana mampu untuk mendukung terselengagranya program keahlian keperawatan tahun ajaran 2018/2019.

Dengan demikian dapat disimpulkan bahwa komponen input pada penyelenggaraan program keahlian keperawatan di SMK PGRI 1 Salatiga tahun ajaran 2018/2019 termasuk dalam kategori baik, karena Program Keahlian Keperawatan telah menjawab kebutuhan stakeholder dan sekolah dengan SDM yang kualifikasi dan jumlahnya memadai, sarpras yang memadai, pendanaan yang memadai, serta mekanisme pelaksanaan yang jelas. Hal tersebut senada dengan penelitian yang 
dilakukan Sunnah dan Sukoco (2014) yang menyatakan bahwa komponen context pada evaluasi sebuah program baik bila dapat memenuhi kebutuhan pemangku kepentingan dengan penyediaan SDM, sarpras, dana yang memadai, juga mekanisme pelaksanaan yang jelas. Pembahaan komponen proses merujuk pada komponen input penelitian ini, perencanaan dalam menyelenggarakan program keahlian keperawatan telah diimplementasikan sesuai dengan mekanisme yang telah ditentukan. Perencanaan untuk kegiatan PPDB, pengembangan kurikulum, IHT, kegiatan belajar mengajar, dan caping day ceremony telah diimplementasikan sesuai dana yang telah dianggarkan. Meskipun terdapat satu kegiatan yang tidak memanfaatkan efektivitas sarana dan prasarana sekolah, namun sebagian besar kegiatan telah diimplementasikan menggunakan sarana dan prasarana sekolah, sehingga sarana dan prasarana yang ada terbilang efektif untuk menunjang terselenggaranya program kehalian keperawatan di SMK PGRI 1 Salatiga tahun ajaran 2018/2019.

Dari segi sumber daya manusia, terlihat bahwa sekolah tidak mengalami kesulitan dalam pemenuhannya. Hal itu karena SDM yang terlibat dalam perencanan hingga implementasi perencanaan tersebut telah sesuai dengan kualifikasinya, dibuktikan dengan ijazah para pendidik dan tenaga kependidikannya. Dari hasil temuan lapangan kegiatan PPDB memperoleh peserta didik baru sebnayak 117 siswa program keahlian keperawatan, jika dilihat dari daftar PPDB tahun ketahun jumlah tersebut mengalami penurunan dari tahun sebelumnya. Hal tersebut juga disampaikan kepala sekolah (wawancara 14 Januari 2020). Tentunya setiap tahun ajaran baru perlu dilakukan pengembangan kurikulum, dan SMK PGRI 1 Salatiga telah mengimplementasikan kegiatan tersebut dengan menggundang pihak Du/Di untuk ikut serta dalam merumuskan pengembangan kurikulum, dengan hasil bahwa pembelajaran di luar kelas akan dilaksanakan pada lokasi Du/Di tersebut berada.

Supaya penyelenggaraan program keahlian keperawatan berjalan dengan baik, maka pengembangan kurikulum tersebut diberitahukan kepada seluruh guru dan karyawan melalui kegiatan in house training (IHT). Dalam kegiatan tersebut juga disampaikan struktur kepengurusan program keahlian keperawatan, sehingga jelas tugas dari setiap anggota. Sedangkan dalam implementasi kegiatan belajar mengajar (KBM) dalam rangka menyelenggarakan program keahlian keperawatan, berjalan dengan baik terlihat dari hasil supervisi kepala sekolah dalam bentuk perangkat dan video saat pembelajaran di dalam kelas maupun laboratorium. Selain itu juga terdapat penilian hasil belajar siswa. Dengan demikian dapat disimpulkan bahwa komponen process pada penyelenggaraan program keahlian keperawatan di SMK PGRI 1 Salatiga tahun ajaran 2018/2019 termasuk dalam kategori baik, karena seluruh rencana kegiatan terlaksana, SDM berfungsi sesuai tupoksinya, dana digunakan secara efisien dan sarparas berfungsi mendukung pelaksanaan kegiatan serta kegiatan terlaksana sesuai jadwal yang ditentukan. Hal tersebut senada dengan penelitian yang dilakukan Salam dan Sunarto (2013) yang menyatakan bahwa proses penyelenggaraan program dapat dikatakan baik jika seluruh perencanaan kegiatan diimplementasikan sesuai jadwal, SDM bekerja sesuai bagian kerja, sarpras yang ada dapat mendukung jalannya kegiatan, dan dengan penggunaan dana sesuai kebutuhan.

Komponen produk dalam Program keahlian keperawatan terlihat bahwa program tersebut telah diselenggarakan sejak tahun 2014, dan pada tahun ajaran 2018/2019 program keahlian keperawatan telah menghasilkan produk lulusan 75 siswa. Data tersebut didapatkan dari data dapodik sekolah. Selain itu kualitas lulusan dari program keahlian keperawatan terbilang kompeten, terlihat dari hasil uji kompetensi yang dilakukan oleh LSP yang telah ditunjuk oleh dinas pendidikan. Namun pada keterserapan lulusan, masih terdapat banyak anak yang bekerja tidak linier dengan program keahlian keperawatan dikarenakan faktor internal peserta didik itu sendiri. Dengan demikian dapat disimpulkan bahwa komponen produk pada evaluasi penyelenggaraan program keahlian keperawatan di SMK PGRI 1 Salatiga tahun ajaran 2018/2019 termasuk dalam kategori cukup karena, jumlah lulusan lebih dari $90 \%$ saat awal masuk, memiliki kualitas lulusan yang kompeten, namun keterserapan sesuai keahlian kurang dari $50 \%$ pada tiap angkatannya yaitu $26,7 \%$. Hal tersebut senada dengan penilitian Mutaqin, Kusnawa, dan Sriyono (2015) menyatakan bahwa keterserapan lulusan SMK yang bekerja sesuai dengan bidangnya di Kota Bandung tahun 2012 dan 2013 kurang dari setengah. Apabila ditinjau secara teoritis masih diselenggarakannya program keahlian keperawatan di SMK PGRI 1 Salatiga tahun ajaran 2018/2019 adalah keputusan yang diambil untuk melakukan perbaikan terhadap program atau sering disebut keputusan incremental (Rose \& Nyre, 1977). 


\section{SIMPULAN}

Berdasar pada hasil penelitian mengenai evaluasi penyelenggaraan program keahlian keperawatan di SMK PGRI 1 Salatiga TA.2018/2019, maka didapatkan beberapa kesimpulan sebagai berikut: 1.) Context penyelenggaraan program keahlian keperawatan di SMK PGRI 1 Salatiga tahun ajaran 2018/2019 termasuk dalam kategori baik, karena didasarkan pada kebutuhan stakeholder dan masyarakat dengan memperhatikan aspek lain seperti: aset, peluang yang dimiliki, dan tujuan program tersebut; 2.) Input penyelenggaraan program keahlian keperawatan di SMK PGRI 1 Salatiga tahun ajaran 2018/2019 termasuk dalam kategori baik, karena telah menjawab kebutuhan stakeholder dan sekolah dengan SDM yang kualifikasi dan jumlahnya memadai, sarpras yang memadai, pendanaan yang memadai, serta mekanisme pelaksanaan yang jelas; 3.) Proses penyelenggaraan program keahlian keperawatan di SMK PGRI 1 Salatiga tahun ajaran 2018/2019 termasuk dalam kategori baik, karena seluruh rencana kegiatan terlaksana, SDM berfungsi sesuai tupoksinya, dana digunakan secara efisien dan sarpras berfungsi mendukung pelaksanaan kegiatan, serta kegiatan terlaksana sesuai dengan jadwal yang ditentukan; dan 4.) Produk penyelenggaraan program keahlian keperawatan di SMK PGRI 1 Salatiga tahun ajaran 2018/2019 termasuk dalam kategori cukup karena, jumlah lulusan lebih dari $90 \%$ saat awal masuk, semua siswa lulus uji kompetensi, namun keterserapan sesuai keahlian kurang dari 50\% pada tiap angkatannya. Hal itu dikarenakan sebagian besar lulusan memilih menetap di Salatiga, sedangkan lowongan pekerjaan yang tetrsedia sebagian besar berada di luar kota.

\section{DAFTAR PUSTAKA}

Adi, N. H. (2018). Evaluasi program prakerin pada kompetensi keahlian teknik komputer dan jaringan di SMKN 2 Lubuk Basung. Jurnal Industri Kreatif, 2(1), 65-73.

Arikunto, S., \& Jabar. C. S. A. (2014). Evaluasi program pendidikan: Pedoman teoritis praktis bagi mahasiswa dan praktisi pendidikan. Jakarta: Bumi Aksara.

Djohar, A. (2007). Pendidikan teknologi dan kejuruan: Dalam ilmu dan aplikasi pendidikan. Bandung: Pedagogiana Press.

Hamalik, O. (2001). Pendidikan tenaga kerja nasional: Kejuruan, kewirausahaan dan manajemen. Bandung: PT. Citra Aditya Bakti.

Hikam, H., \& Sari, S. P. (2017, 20 Agustus). Ternyata pendidikan vokasi penting untuk kesuksesan, kok bisa?. Retrieved from https://news.okezone.com/read/2017/08/18/65/1758345/ ternyata-pendidikan-vokasi-penting-untuk-kesuksesan-kok-bisa

Hermawan, H., \& Fatimah, S. (2017, 14 Agustus). Pentingnya pendidikan vokasi di era global. Retrieved from https://news.okezone.com/read/2017/08/13/65/1755129/catat-pentingnyapendidikan-vokasi-penting-di-era-global

Ixtiarto, B., \& Sutrisno, B. (2016). Kemitraan Sekolah Menengah Kejuruan dengan dunia usaha dan dunia industri (Kajian aspek pengelolaan pada SMK Muhammadiyah 2 Wuryantoro Kabupaten Wonogiri). Jurnal Pendidikan Ilmu Sosial, 26(1), 57-69. doi:https://doi.org/10.2317/jpis.v26i1.2130

Lestari, Y. (2018). Konsep dasar keperawatan. Yogyakarta: Andi Offset

Muliati, A. M. (2007). Evaluasi program pendidikan sistem ganda: Suatu penelitian evaluatif berdasarkan Stake's Countenance model mengenai program pendidikan sistem ganda pada sebuah SMK di Sulawesi Selatan (2005/2007). Retrieved from https://docplayer.info/75311-A-muliati-a-m-2-abstract.html

Mutaqin, M. K. A., Kusnawa, W. S., \& Sriyono, S. (2015). Studi eksplorasi keterserapan lulusan Sekolah Menengah Kejuruan Negeri Di Kota Bandung pada industri otomotif. Journal of Mechanical Engineering Education, 247-252. doi:https://doi.org/10.17509/jmee.v2i2.1486 
Ngadi, N. (2014). Relevansi pendidikan kejuruan terhdap pasar kerja di kota Salatiga. Jurnal kependudukan Indonesia, 9(1), 59-69.

Rose, C., \& Nyre, G. F. (1977). The practice of evaluation. Princetion: Education Testing Service.

Salam, R., \& Sunarto, S. (2013). Evaluasi pelaksanaan program SMK kelas jauh di MAN Karangayar. Jurnal Pendidikan Vokasi, 3(2), 257-261. doi:https://doi.org/10.21831/jpv.v3i2.1605

Soesatyo, B., \& Ilyasa. (2018, 3 Agustus). Ketua DPR beberkan pentingnya pendidikan vokasi. Retrieved from http://www.teropongsenayan.com/90360-ketua-dpr-beberkan-pentingnyapendidikan-vokasi

Sugiyono, S. (2013). Metode penelitian pendidikan pendekatan kuantitatif, kualitatif, dan $R \& D$. Bandung: Alfabeta.

Sunnah, A., \& Sukoco. (2014). Evaluasi pelaksanaan program SEAMOLEC di SMK daerah Istimewa Yogyakarta. Jurnal Pendidikan Vokasi, 4(2), 145-163. doi:https://doi.org/10.21831/jpv.v4i2.2542

Suparlan, S. (2017). Wawasan pendidikan: Sebuah pengantar pendidikan. Yogyakarta: ArRuzzmedia. 